\title{
Macroinvertebrate biodiversity patterns during primary succession in manmade ponds in north-eastern Spain
}

\author{
Leticia MIGUEL-CHINCHILLA, ${ }^{1 *}$ Dani BOIX, ${ }^{2}$ Stéphanie GASCÓN,${ }^{2}$ Francisco A. COMÍN ${ }^{1}$ \\ ${ }^{1}$ Pyrenean Institute of Ecology, Spanish Council of Science, Avda. Montañana 1005, 50059 Zaragoza, Spain; ${ }^{2}$ Institute of Aquatic \\ Ecology, Faculty of Sciences, University of Girona 17071, Girona, Spain \\ *Corresponding author: leticia.m.ch@gmail.com
}

\begin{abstract}
The aim of this work was to evaluate the primary succession of manmade ponds by studying the temporal patterns of the pond biodiversity metrics. We surveyed the macroinvertebrate community, the water and the sediment of 19 manmade ponds of different ages (from 1 to 22 years) located at reclaimed opencast coal mines in north-eastern Spain. This study showed an increase of biodiversity with pond age: the oldest ponds showed higher complexity and more rare taxa than the youngest ponds, while the taxonomic richness did not change. These results highlighted the need for using a wide range of biodiversity metrics. Moreover, our results suggest that post-mining landscapes could be limiting environments for the evolving macroinvertebrate community because pond age explained less of the biodiversity variance than the environmental characteristics. The changes found in water and sediment during this time were not reflected in changes in biodiversity, and the levels of biodiversity in our study area were lower than those of restored or manmade ponds of similar ages.
\end{abstract}

Key words: Pond age, taxonomic distinctness, rarity, richness, chrono-sequence approach, opencast coal mines.

Received: December 2013. Accepted: February 2014.

\section{INTRODUCTION}

Succession (defined here as the process of change in species composition in an ecosystem over time) is a key process related to the functioning of the ecosystem (Margalef, 1968; Odum, 1969; Gutiérrez and Fey, 1980). Therefore, we think that a deep knowledge about succession is essential to understand ecological processes. Recent studies have shown high pond contribution to biodiversity and geochemical cycles among other ecological functions (Oertli et al., 2002; Williams et al., 2004; Zedler and Kercher, 2005). Although ponds have been neglected by scientific community, the number of constructed ponds increase and they were a perfect scenario to study succession trajectories (De Meester et al., 2005; Céréghino et al., 2008; Boix et al., 2012; Ruhí et al., 2013). Moreover, a deeply knowledge about temporal patterns of the community is required in order to improve the success in restoration projects, which have as objective restore the structure of the expected natural community and to enhance biodiversity (Gallardo et al., 2011; Ruhí et al., 2012; Moreno-Mateos et al., 2012).

The knowledge about the basic processes driving primary succession in wetlands remains limited (Noon, 1996), particularly with respect to changes in the faunal community (Batzer et al., 2006). Moreover, most successional studies have been based on temporary wetlands and therefore strictly analyzed secondary succession processes
(Lake et al., 1989; Boix et al., 2004). Manmade ponds form excellent model systems for analyzing the primary succession process because pond construction allows to study community composition from the onset of habitat creation (Velasco et al., 1993; Flory and Milner, 2000; Matthews et al., 2009). So, to study manmade ponds allows to improve primary succession knowledge and offers new information to support to design most efficient ecosystems in relation to their construction objectives.

Biodiversity, studied as community composition, is a suitable community metric for studying primary succession because it is important in maintaining the biogeochemical cycles and functioning of the ecosystem (Loreau et al., 2001; Hooper et al., 2005). However, empirical studies describing how biodiversity changes over time in manmade ponds are scarce and most of these studies focused on changes in taxonomic richness. Traditional ecological papers hypothesized that there is an increase in biomass and taxonomic richness during succession (Odum, 1969; Gutiérrez and Fey, 1980; Legendre et al.,1985). Some authors verified an increase in richness during the initial colonization of newly created ponds (Barnes, 1983; Ruhí et al., 2009, 2012; Marchetti et al., 2010). However, after the initial changes in biodiversity, the rate of acquisition of new species tends to decline within a few years from the onset of succession (Barnes, 1983; Fairchild et al., 1999; Proctor and Grigg, 2006; Marchetti et al., 2010), indicating an equilibrium in the 
number of species, as predicted by the theory of island biogeography (MacArthur and Wilson, 1967; Whittaker and Fernández-Palacios, 2007). Moreover, over longer time scales, unimodal responses may also be present (Rosenzweig, 1992; Hansson et al., 2005), while other authors found no pattern in long-term studies regarding biodiversity when using taxonomic richness (Gee and Smith, 1995; Spieles et al., 2006). Nevertheless, no single index alone is a suitable surrogate to represent overall biodiversity community dynamics (Warwick and Clarke, 1995; Wilsey et al., 2005; Heino et al., 2007). Taxonomic richness alone may not represent all of the biodiversity aspects of the community and therefore has been over used as a measure of biodiversity (Bilton et al., 2006; Gallardo et al., 2011). Other metrics, such as taxonomic distinctness and rarity, that take into account complementary aspects of the concept of biodiversity, should be considered (Warwick and Clarke, 1995). These two biodiversity aspects illustrate different but complementary techniques of inferring community characteristics (Heino et al., 2007; Gascón et al., 2009). For example, it has been suggested that pioneering taxa are taxonomically highly related, and lower values of taxonomic distinctness are expected at the initial phases of succession (Ruhí et al., 2009). Moreover, it has been reported that as succession progresses, colonization is mainly driven by the erratic arrival of dispersers with lower dispersal abilities (Ruhí et al., 2013). Therefore, at later successional phases, an increase in the rarity values of macroinvertebrate assemblages is expected due to the erratic arrivals of such taxa that also may produce increased taxonomic unevenness. Accordingly, we expected that taxonomic distinctness and rarity change during primary succession.

To analyze primary succession an extensive temporal range of data is needed, in other case only colonization phase could be considered (Zedler and Callaway, 1999; Fairchild et al., 2000; Ruhí et al., 2012). However, obtain long-term series of data usually is a difficult issue and to overcome this problem, space-for-time approaches has frequently been adopted (e.g., Barnes, 1983; Fukami and Wardle, 2005; Bloechl et al., 2010). The present study focused on macroinvertebrate organisms from manmade ponds constructed at different time-periods during reclamation activities at opencast coal mines. Consequently, the studied ponds have different ages (from 1 to approx. 22 years old). Ponds were located in post-mining landscapes reclaimed with similar techniques, shared similar substrate and were affected by similar climatic conditions which made them appropriate for the use of the chronosequence approach for studying primary succession (Majer and Nichols, 1998; Walker et al., 2010). Thus, our main objective was to analyze the temporal patterns of biodiversity during primary succession using complementary biodiversity metrics. We considered several questions: i)
Is biodiversity changing over time? ii) Are temporal changes in biodiversity related to environmental changes (and if so, to which factors)? iii) Is pond age the main factor explaining the variation in biodiversity? To answer these questions, we studied the biodiversity of the macroinvertebrate community and the environmental characteristics (water, sediment and landscape) of a set of manmade ponds constructed at different times during opencast coal mining reclamation. Due to the particular characteristics of the study site, we included a fourth question: iv) Is the biodiversity of manmade ponds constructed in post-mining landscapes similar to the biodiversity of manmade ponds constructed in other environmental conditions?

\section{METHODS}

\section{Study site}

The current study was conducted in north-eastern Spain (Teruel Province), which is characterized by a continental Mediterranean climate. The manmade ponds sampled in this study (Fig. 1) were constructed during the reclamation process of several coal mines. In this region, coal mines worked the same coal seam with similar extraction methods and followed comparable reclamation patterns. The manmade ponds were all created for the same purpose, to manage the water runoff produced in the reclaimed mines to avoid contaminating natural ecosystems but not with the specific objective of enhancing the biodiversity values of the region. Following our study site knowledge, we selected 19 manmade ponds, covering an age range of 22 years, that were as similar as possible in their physical characteristics. Thus, the manmade ponds have endorheic basins and are isolated from watercourses, except for two ponds connected by a small stream. All of the manmade ponds are permanent and have similar water level fluctuations as well as oval shapes and their size were among 0.2 and 5 ha (with a size mean of $1.5 \mathrm{ha}$ ). Typha sp. (among the only macrophytes found in the manmade ponds) grows at high-density in the banks of the ponds, except for three ponds where macrophytes were scarce or absent. No natural ponds formerly existed in the river basin where the mines are located.

\section{Sampling and sample processing}

Two surveys were conducted: one in the spring and one in the summer of 2009. In each pond, samples of macroinvertebrates, water and sediment were collected, and pond and landscape characteristics were measured.

\section{Macroinvertebrate sampling}

Macroinvertebrate collections were restricted to shallow sites $(<1 \mathrm{~m}$ deep) located in the littoral of the man- 
made ponds. One integrated sample from the major mesohabitats (emergent plants, bottom and water column) was collected from each pond with a $250-\mu \mathrm{m}$-mesh hand-net using the kick-and-sweep sampling technique. Sampling was considered complete when no new taxa were found by visual observation. The macroinvertebrate samples were preserved in $4 \%$ formalin. The samples were washed through nested sieves in the laboratory and the collected fauna was sorted under a stereomicroscope and identified mostly to the genus level (except for the Oligochaeta and Diptera).

\section{Water characteristics}

Dissolved oxygen, temperature, conductivity and $\mathrm{pH}$ were measured in situ using portable probes (WTW ${ }^{\circledR}$ Multiline P4, Weilheim, Germany). Water samples were collected at a depth of $15-20 \mathrm{~cm}$ and brought to the lab for further analyses. Chlorophyll- $a$ was analyzed by spectrophotometry. Alkalinity $\left(\mathrm{mg} \mathrm{L}^{-1}\right)$ was determined by $\mathrm{pH}$ potentiometric automatic titration with $0.004 \mathrm{~N} \mathrm{H}_{2} \mathrm{SO}_{4}$ $\left(\right.$ Metrohm $^{\circledR}$, Herisau, Switzerland). Water samples were filtered through pre-ashed glass-fibre filters. Total suspended solids and total suspended organic matter were calculated by filter and burned filter weight differences, respectively.
Total dissolved nitrogen ( $\left.\mathrm{mg} \mathrm{L}^{-1}\right)$ and non-purgeable organic carbon $\left(\mathrm{mg} \mathrm{L}^{-1}\right)$ were determined by catalytic combustion at high temperature using a Multi-N/C 3100 analyzer (Analytik Jena ${ }^{\circledR}$, Jena, Germany). In addition, we determined total dissolved phosphorus and 10 dissolved trace metals (mg L ${ }^{-1}$ ), Al, As, Cd, Cr, Cu, Fe, Mn, Ni, Pb and Zn, using Inductively Coupled Plasma Optical Emission Spectrometry (ICP-OES iCAP6300Duo; Thermo Fisher $^{\circledR}$, Waltham, MA, USA). Analyses performed in the laboratory followed the standard methods of the American Public Health Association (APHA et al., 1992). All the materials used for metal analysis were soaked in 10\% HNO3 (Sastre et al., 2002).

\section{Sediment characteristics}

One composite sample of sediment was collected in the littoral zone of each pond. Sediment $\mathrm{pH}$ and conductivity $\left(\mu \mathrm{S} \mathrm{cm}^{-1}\right)$ were measured in a solution of $10 \mathrm{~g}$ of fresh sediment dispersed in deionised water ( $\mathrm{pH}: 2.5: 1 \mathrm{~g}$ $\mathrm{mL}^{-1}$, conductivity: $5: 1 \mathrm{~g} \mathrm{~mL}^{-1}$ ) after shaking for $30 \mathrm{~min}$. The collected sediments were air dried and sieved into fractions. For the $<2-\mathrm{mm}$ sieved sediment, we calculated the particle-size by laser-diffraction analysis (Syvitski, 2007) using a Mastersizer $2000^{\circledR}$ particle size analyzer

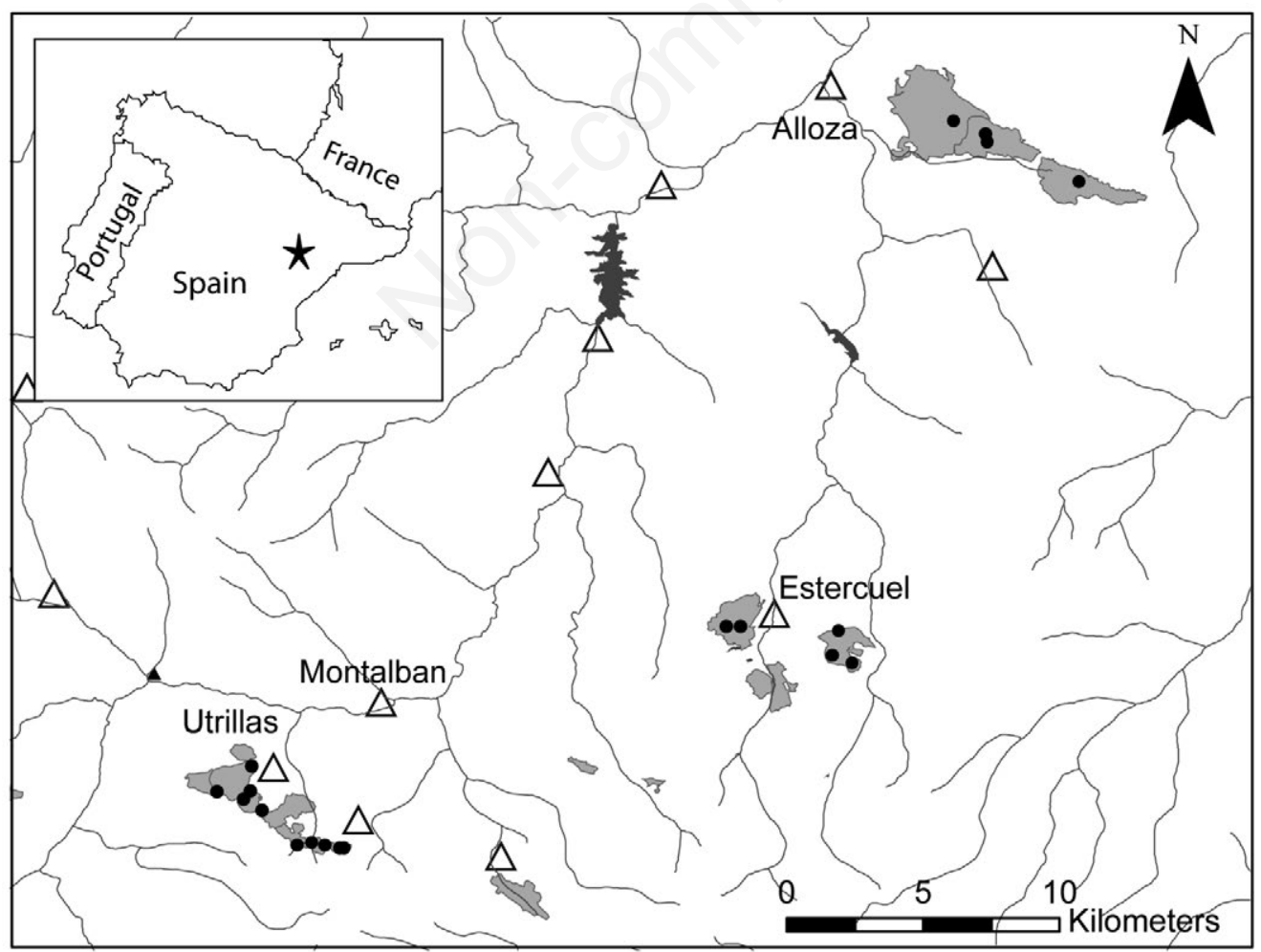

\section{Legend}

$\star$ Study site

- Manmade pond

River

Reservoir

Opencast coal mine Village

Fig. 1. Study site and pond locations. 
(Malvern Instruments, Malvern, UK). We obtained the percentage of sand, thick silt, thin silt and clay. The $<2$ $\mathrm{mm}$ fraction was also used to determine total carbon (\%), total inorganic carbon (\%) and total sulphur (\%) using an elemental analyzer (LECO SC-144DR; Leco Instruments $^{\circledR}$, St. Joseph, MI, USA). Total organic carbon (\%) was calculated by the difference between total carbon and total inorganic carbon. Total nitrogen (\%) was determined using an elemental analyzer (Variomax ${ }^{\circledR} \mathrm{CN}$ ). The $<63$ $\mu \mathrm{m}$ fraction was used to determine total phosphorus (mg $\mathrm{kg}^{-1} \mathrm{DW}$ ) and total heavy metals ( $\left.\mathrm{mg} \mathrm{kg}^{-1} \mathrm{DW}\right)$ : $\mathrm{Al}, \mathrm{As}$, $\mathrm{Cd}, \mathrm{Cr}, \mathrm{Cu}, \mathrm{Fe}, \mathrm{Mn}, \mathrm{Ni}, \mathrm{Pb}$ and $\mathrm{Zn}$. The phosphorus and metals were microwave extracted (Speedwave MWS-3, Berghof, Germany), following the methods of the US Environmental Protection Agency (EPA, 2007) and then determined using ICP-OES following the American Public Health Association methods (APHA et al., 1992).

\section{Landscape characteristics}

Pond and landscape characteristics were estimated with geographic information systems (ArcGis 9.3.1 Esri) and fieldwork observations. We calculated pond area $\left(\mathrm{m}^{2}\right)$, pond littoral slopes (\%), pond basin slope (degrees), vegetated pond littoral area $\left(\mathrm{m}^{2}\right)$, distance to nearest pond $(\mathrm{m})$, distance to nearest river ( $\mathrm{m}$ ), the numbers of ponds in a 1000$\mathrm{m}$ buffer and the number of rivers in a 1000-m buffer.

\section{Data analysis}

\section{Biodiversity metrics}

As the macroinvertebrate sampling effort was not comparable among ponds, to characterize the macroinvertebrate community, we calculated four biodiversity metrics that did not require abundance estimations: rarefied richness, average taxonomic distinctness, variance of taxonomic distinctness and index of faunal originality as the rarity index. Biodiversity metrics were calculated for each pond in each season.

Species richness increases with sample size, and differences in richness may be caused by sampling differences (Oksanen et al., 2009). Rarefaction is a method for comparing species richness between treatments, after standardization, to account for sampling effort. Therefore, rarefied richness (RR) minimizes the differences between the sampling effort, collection conditions and organism abundances (Gotelli and Colwell, 2001). In this case, RR was standardized according to the minimum number of invertebrate collected in one sample using the rarefy function that was available in the Vegan package (Oksanen et al., 2009), which is a statistical package that provides tools for descriptive community ecology developed for the R statistical software (R Core Team, 2012). Taxonomic distinctness metrics consider the relatedness of species in each sample incorporating the phylogenetic re- lationships among taxa (Clarke and Warwick, 1998). We considered two taxonomic distinctness metrics, Average taxonomic distinctness (AvTD) and Variance in taxonomic distinctness (VarTD) because they are not sensitive to variation in sampling effort and are calculated with presence-absence data (Clarke and Warwick, 1998). AvTD is the mean path length between any two randomly chosen taxa traced through a Linnaean or phylogenetic classification of the full set of documented taxa (Clarke and Warwick, 1998) and is a proxy of the taxonomic relatedness of the taxa encountered in the analyzed assemblage. In comparison, VarTD is the variance of these pairwise path lengths and reflects the unevenness of the taxonomic tree (Clarke and Warwick, 2001). AvTD and VarTD were calculated with PRIMER v6 using a setting of 100 , which is the longest path length in taxonomy. The path lengths between the different taxonomic levels of the classification tree (based on standard Linnaean hierarchical classification) were considered equal. Six taxonomic levels (genus, family, order, class, phylum and kingdom) were considered in the aggregation file. Finally, we calculated the rarity of the macroinvertebrate community through the Index of Faunal Originality (IFO), which only needs presence-absence data and is, therefore, independent of the taxonomic abundance. IFO was calculated for each manmade pond according to Puchalski (1987):

$$
I F O=\frac{\sum_{i=1}^{S}\left(1 / M_{i}\right)}{S}
$$

where $M$ is the total number of samples in which taxon $i$ occurs (total number of manmade ponds in which a particular taxon appears) and $S$ is the total number of taxa in the corresponding sample (the total number of taxa in the manmade pond for which the index is calculated). The theoretical maximal value of the index is 1 , indicating that none of the taxa found in one pond were recorded in another pond.

\section{Statistical analysis}

The ponds were grouped into four age categories (Pond Age Categories, hereafter PAC) for statistical analysis: PAC1, $1-5$ years (5 ponds); PAC2, 6-10 years (5 ponds); PAC3, 11-15 years (4 ponds); and PAC4, 1622 years ( 5 ponds).

To explore biodiversity changes across the PACs, we used linear mixed models (LMM), with PAC as the fixed effect and season as a random effect. The inclusion of season in the random part of the model allowed us to control pseudo-replication problems due to sampling each pond in two different seasons (Hurlbert, 1984). We performed the linear mixed models using the lme function integrated in the nlme package (Pinheiro et al., 2012) designed for R statistical software (R Core Team, 2012). A ln-transfor- 
mation of IFO was needed to improve the error fitness to a normal distribution.

The biodiversity levels of the manmade ponds constructed in the reclaimed opencast coal mines were compared with data from other studies undertaken with manmade or restored wetlands and ponds of different ages. We selected nine studies Barnes (1983), Hov and Walseng (2003), Solimini et al. (2003), Lancaster et al. (2004), Spieles et al. (2006), Proctor and Grigg (2006), Ruhí et al. (2009), Marchetti et al. (2010), and Ruhí et al. (2012) that considered some of the biodiversity metrics used in this study (RR, AvTD, VarTD and IFO) or offered taxonomic lists that allowed their calculation. Note than in Ruhí et al. (2009), we only considered the data for permanent manmade ponds.

To determine whether the environmental characteristics of the manmade ponds vary over time, we used two discriminant analyses (DA), one for water (water-DA) and another for sediment (sediment-DA) characteristics. DA is a multivariate method that generates a series of discriminant functions based on linear combinations of predictor variables that provide the best possible discrimination (or maximal separation) between pre-established groups (Hair et al., 2005; Corstanje et al., 2009). Therefore, DA allows for the statistical determination of significant differences in water and sediment characteristics among the four PACs and thus determines whether environmental characteristics change significantly over time. These analyses were carried out using SPSS 19 for Windows (SPSS Inc., Chicago, IL, USA). Before the analysis, all variables, except $\mathrm{pH}$, were $\log (\mathrm{x}+1)$ transformed. To reduce multi-collinearity problems in the DA, we excluded from the analysis those highly associated metrics (of water and sediment datasets) based on Spearman rank correlations (if $\mathrm{P}<0.01$ and $\mathrm{r}_{\mathrm{s}} \geq 0.7$; Myers 1986). In such cases only one of the metrics was retained.

Finally, we performed variation partitioning analyses to quantify the proportion of biodiversity variability explained by the four groups of predictors considered in this study: PAC, water, sediment and landscape datasets. This analysis breaks down and quantifies the explained variation in the dependent variables (biodiversity metrics) as pure (or unique) and shared (or joint) effects of a set of predictors (age and environmental datasets). Thus, we distinguished three type of effects: pure (the variation explained by only one dataset without considering the effects the other datasets included in the analysis), shared (the variation explained by one dataset and its interaction with other datasets included in the analysis) and global (the variation explained by one dataset and its interaction with all the datasets included in the analysis). For more information about variation partitioning see Borcard et al. (1992), Heikkinen et al. (2005), Peres-Neto et al. (2006) and Wang et al. (2011). The variation partitioning analy- ses is integrated in the varpart function as part of the Vegan package (Oksanen et al., 2009) available for the $\mathrm{R}$ statistical software (R Core Team, 2012). One variance partitioning analysis was performed with each biodiversity metric: RR, AvTD, VarTD and IFO. Before performing variation partitioning, we identified the predictor variables within each dataset (water, sediment and landscape) having independent impacts on the biodiversity metric to only include the environmental variables that significantly explain the variability of each metric in each analysis. We identified these variables by the use of the 'rand.hp' function, which is a randomization routine integrated into the 'hier.part' package (MacNally and Walsh, 2004) available for the R statistical software (R Core Team, 2012) and which focuses on the analysis of the variance partition of a multivariate data set. This analysis showed the independent contribution toward the explained variance in a multivariate dataset. The results of 'rand.hp' were expressed as Z-scores and the statistical significance was based on the upper $95 \%$ confidence limits ( $Z \geq 1.65$; MacNally 2002).

\section{RESULTS}

\section{Biodiversity changes across ponds of different ages}

Although RR did not show any significant response through successional stages (i.e., PAC), the other three biodiversity metrics did. AvTD, VarTD and IFO significantly increased with pond age (Fig. 2), indicating that as ponds mature, the macroinvertebrate assemblages that inhabit them increase in rarity (IFO), average taxonomic distinctness (AvTD) and unevenness of the taxonomic tree (VarTD). The faunal list by PAC is shown in Tab. 1.

\section{Water and sediment characteristics among pond age categories}

The variables included in the water-DA selected after determining the correlations were: chlorophyll-a concentration, $\mathrm{pH}$, conductivity, alkalinity, non-purgeable organic carbon, total dissolved nitrogen, total dissolved phosphorus, $\mathrm{Al}, \mathrm{As}, \mathrm{Cr}, \mathrm{Cu}$ and $\mathrm{Ni}$. The variables used in the sediment-DA were: $\mathrm{pH}$, total inorganic carbon, total organic carbon, total sulphur, thin silt fraction, clay fraction, $\mathrm{As}, \mathrm{Cr}, \mathrm{Cu}, \mathrm{Fe}, \mathrm{Mn}, \mathrm{Ni}$ and $\mathrm{Zn}$.

The discriminant analysis of the water characteristics showed that only the first of the three discriminant functions (DF) was significant in differentiating PACs based on the $\chi^{2}$ test $(\mathrm{P}<0.05)$. The first DF showed a high canonical correlation with PAC $(\rho=0.827)$ and accounted for $67.2 \%$ of the explained variance. The first three DFs were significant for sediment characteristics $(\mathrm{P}<0.05)$. All three had a significantly high canonical correlation coefficient with PAC ( $\rho=0.916,0.834$ and 0.801 ), accounting from $56.2 \%$ of the explained variance for the first DF to $19.2 \%$ 
for the third DF. Both water-DA and sediment-DA clearly discriminated youngest ponds (PAC1) from the rest of the ponds (Fig. $3 \mathrm{~A}, \mathrm{~B}$ ). The differences in water characteristics (Fig. 3A) were related to total nitrogen content, which was the variable better correlated to the first $\mathrm{DF}(\mathrm{r}=0.453)$, indicating that younger ponds had higher nitrogen concentrations.

The first DF obtained with the sediment dataset (Fig. 3B) was positively correlated with total organic carbon $(\mathrm{r}=0.361)$, total sulphur $(\mathrm{r}=0.221)$ and several heavy metals (iron $\mathrm{r}=0.250$; arsenic $\mathrm{r}=0.244$; and chromium $\mathrm{r}=0.208$ ), while the $\mathrm{pH}(\mathrm{r}=-0.286)$ and total manganese content $(\mathrm{r}=$ -0.236 ) were negatively correlated. Thus, youngest ponds had less total organic carbon and metal content than older ponds. Both DAs indicated that the youngest ponds (PAC1) were different in their environmental characteristics compared to the other three PACs. Consequently, the main environmental changes were detected when comparing youngest ponds (from 0 to 5 years old) with older ponds (from 6 to 22 years old), in which environmental conditions remained similar (Fig. $3 \mathrm{~A}$ and B).

\section{Factors explaining the biodiversity variability}

The variation partitioning results (Tab. 2), performed after variable selection (see Tab. 3 to identify selected variables after the randomization routine) showed that the
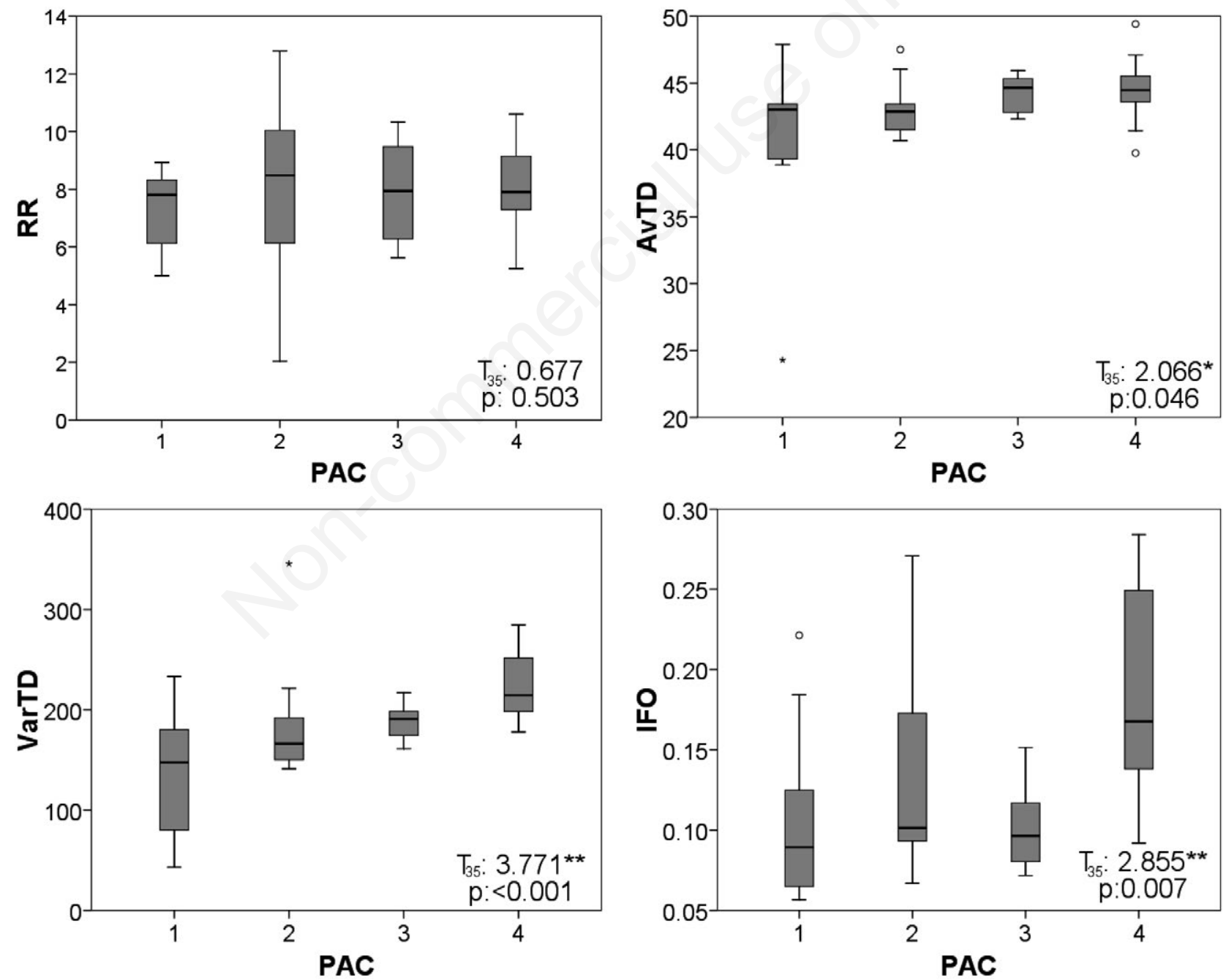

Fig. 2. Long-term biodiversity trends. The values of each biodiversity metric (RR, rarefied richness; AvTD, average taxonomic distinctness; VarTD, variation in taxonomic distinctness; IFO, index of faunal origin) are represented by the pond age category (PAC). Spearman correlations and p-values are shown. Box-plots symbols: dark grey box, interquartile range (IQR: Q3-Q1); black horizontal line within the dark grey box, median (Q2); upper whisker, upper (Q3+1.5IQR); lower whisker, lower (Q1-1.5IQR); circle, mild outlier: asterisk, extreme outlier. 
proportion of variation explained by pond age, water, sediment and landscape datasets varied with respect to the biodiversity metrics analyzed. Overall, the environmental characteristics and pond age explained a higher proportion of the variation in the taxonomic distinctness metrics (more than 50\%) than in RR and IFO (less than 40\%). This indicates that the age and the environmental characteristics of the ponds contributed significantly, but to a lesser extent, to the observed variation in taxonomic richness and abundance of rare taxa. Our results showed that the observed variability in biodiversity metrics was not purely explained by pond age. When also accounting for the shared variability of pond age with the other environmental variables (i.e., the global pond age effect), pond age significantly explained VarTD and IFO variability (Tab. 2). Water (pure and global) significantly explained some of the variability in RR and VarTD and also explained some of the variability in IFO, when considered in relation to the other data sets (global effect). Sediment was significant for AvTD, VarTD and IFO only with re-

Tab. 1. Taxonomic distribution of macroinvertebrates found in each pond age categories.

\begin{tabular}{|c|c|c|c|c|c|c|c|c|c|c|c|}
\hline \multicolumn{8}{|c|}{ Pond age category } & \multicolumn{4}{|c|}{ Pond age category } \\
\hline Group & Taxa & 1 & 2 & 3 & 4 & Group & Taxa & 1 & 2 & 3 & 4 \\
\hline \multirow[t]{30}{*}{ Coleoptera } & Donacia & + & + & + & - & Diptera & Eriopterini & - & - & - & + \\
\hline & Dryops & + & - & - & - & & Pericoma & - & - & - & + \\
\hline & Acilius & + & + & - & + & & Tenatocera & + & - & - & - \\
\hline & Bidessus & + & + & - & - & & Nemotelus & - & - & - & + \\
\hline & Coelambus & + & + & - & - & & Odontomyia & - & + & - & + \\
\hline & Copelatus & + & + & - & - & & Oxycera & - & + & - & + \\
\hline & Eretes & + & + & - & + & & Tipula & - & - & - & + \\
\hline & Graptodytes & + & + & + & + & Ephemeroptera & Cloeon & + & + & + & + \\
\hline & Hydroglyphus & + & + & - & - & & Procloeon & - & + & + & + \\
\hline & Hydroporus & + & + & - & - & & Caenis & + & + & + & + \\
\hline & Hygrobia & - & + & - & - & & Ephemera & + & + & + & + \\
\hline & Hygrotus & - & + & - & - & & Thraulus & - & + & - & + \\
\hline & Hyphydrus & + & + & + & - & Hemiptera & Corixa & + & + & + & + \\
\hline & Ilybius & + & + & + & + & & Cymatia & + & + & + & + \\
\hline & Laccophilus & + & + & + & + & & Micronecta & + & + & + & + \\
\hline & Meladema & - & - & - & + & & Sigara & - & + & - & - \\
\hline & Scarodytes & - & - & - & + & & Gerris & + & + & + & + \\
\hline & Yola & + & + & - & + & & Mesovelia & - & - & + & - \\
\hline & Limnius & + & - & - & - & & Naucoris & + & + & + & + \\
\hline & Gyrinus & - & + & - & - & & Anisops & + & - & + & - \\
\hline & Haliplus & + & + & + & + & & Notonecta & + & + & + & + \\
\hline & Helophorus & - & + & + & & & Plea & + & + & + & + \\
\hline & Limnebius & - & - & - & + & Megaloptera & Sialis & - & - & - & + \\
\hline & Berosus & + & + & + & + & Odonata & Anax & + & + & + & + \\
\hline & Hydrochara & & + & - & - & & Aeshna & - & + & - & + \\
\hline & Helochares & + & + & + & - & & Gomphus & - & + & - & + \\
\hline & Laccobius & - & - & - & + & & Onychogomphus & - & + & - & - \\
\hline & Hydrochus & - & - & + & - & & Coenagrion & + & + & + & + \\
\hline & Noterus & - & + & + & + & & Ceriagrion & - & + & - & - \\
\hline & Hydrocyphon & - & - & - & + & & Ischnura & + & + & + & + \\
\hline \multirow[t]{16}{*}{ Diptera } & Ceratopogonidae & + & + & + & $\overline{+}$ & & Lestes & + & + & + & + \\
\hline & Orthocladiinae & + & + & + & + & & Sympecma & + & + & + & + \\
\hline & Chironomini & + & + & + & + & & Crocothemis & + & + & + & + \\
\hline & Tanypodinae & + & + & + & + & & Libellula & - & - & + & - \\
\hline & Tanytarsini & + & + & + & + & & Orthetrum & + & + & + & + \\
\hline & Anopheles & + & + & + & + & & Sympectrum & + & + & + & + \\
\hline & Culex & - & + & - & + & & Platycnemis & - & - & - & + \\
\hline & Culiseta & - & - & - & + & Trichoptera & Ecnomus & - & - & + & + \\
\hline & Dixella & - & + & + & + & & Allotrichia & + & + & + & - \\
\hline & Dolichopodidae & + & + & - & + & & Setodes & + & - & + & + \\
\hline & Hydrellia & + & - & - & - & & Micropterna & - & - & - & + \\
\hline & Scatella & + & + & - & + & & Agrypnia & - & - & - & + \\
\hline & Dicranomyia & - & + & + & - & & Plectrocnemia & + & - & - & - \\
\hline & Helius & - & + & + & + & Oligochaeta & Tubificidae & + & + & + & + \\
\hline & Pilaria & - & - & - & + & & & & & & \\
\hline & Rhypholophus & + & - & - & - & & & & & & \\
\hline
\end{tabular}


spect to the global effect and, similarly, landscape only had significant global effects in explaining the variability of RR, AvTD and VarTD. In general, the proportion of variation explained by environmental characteristics was higher than the variation explained by pond age for any of the biodiversity metrics tested, indicating a small effect of pond age on biodiversity.

\section{DISCUSSION}

Curiously, taxonomic richness, the most widely used index of biodiversity, was the only metric that did not show any significant response when comparing pond age categories. Other studies performed in constructed (Gee et al., 1997) or restored wetlands (Marchetti et al., 2010) of similar life spans (from 0 to 20/25 years in age) also failed to detect a long-term increase in taxonomic richness, although Marchetti et al. (2010) detected an increase in richness during the first five years after pond restoration.

This result does not necessarily mean that community composition does not change. Spieles et al. (2006) found a change in guild dominance across time, although basic community metrics (richness and abundance) showed no significant differences over a 10-year range. Similarly, the number of taxa in our study did not change significantly, whereas the taxonomic structure of the assemblages and rarity did (Fig. 2). Colonization processes in newly created
Tab. 2. Results of the variation partitioning analysis for the biodiversity metrics with respect to water, sediment, landscape and pond age categories. The proportions of unexplained, pure, global and shared variations are shown for pond age and the other three sets of variables.

\begin{tabular}{|c|c|c|c|c|c|}
\hline & & $\mathrm{RR}$ & AvTD & VarTD & IFO \\
\hline \multirow[t]{2}{*}{ Water } & Pure & $0.12 *$ & 0.17 & $0.20 * *$ & 0.10 \\
\hline & Global & $0.31 * *$ & 0.51 & $0.62^{* *}$ & $0.20 *$ \\
\hline \multirow[t]{2}{*}{ Sediment } & Pure & - & -0.01 & 0.04 & 0.13 \\
\hline & Global & - & $0.15^{*}$ & $0.42^{* *}$ & $0.29 *$ \\
\hline \multirow{2}{*}{ Landscape } & Pure & 0.04 & 0.03 & 0.01 & - \\
\hline & Global & $0.27 * *$ & $0.33^{* *}$ & $0.39 * *$ & - \\
\hline \multirow[t]{2}{*}{ PAC } & Pure & 0.00 & 0.00 & 0.04 & -0.02 \\
\hline & Global & -0.01 & 0.07 & $0.27^{* *}$ & $0.14 * *$ \\
\hline PAC and water & Shared & -0.03 & 0.07 & 0.20 & 0.09 \\
\hline PAC and sediment & Shared & - & 0.08 & 0.23 & 0.16 \\
\hline PAC and landscape & Shared & 0.00 & 0.07 & 0.24 & - \\
\hline Unexplained & & 0.63 & 0.47 & 0.26 & 0.62 \\
\hline
\end{tabular}

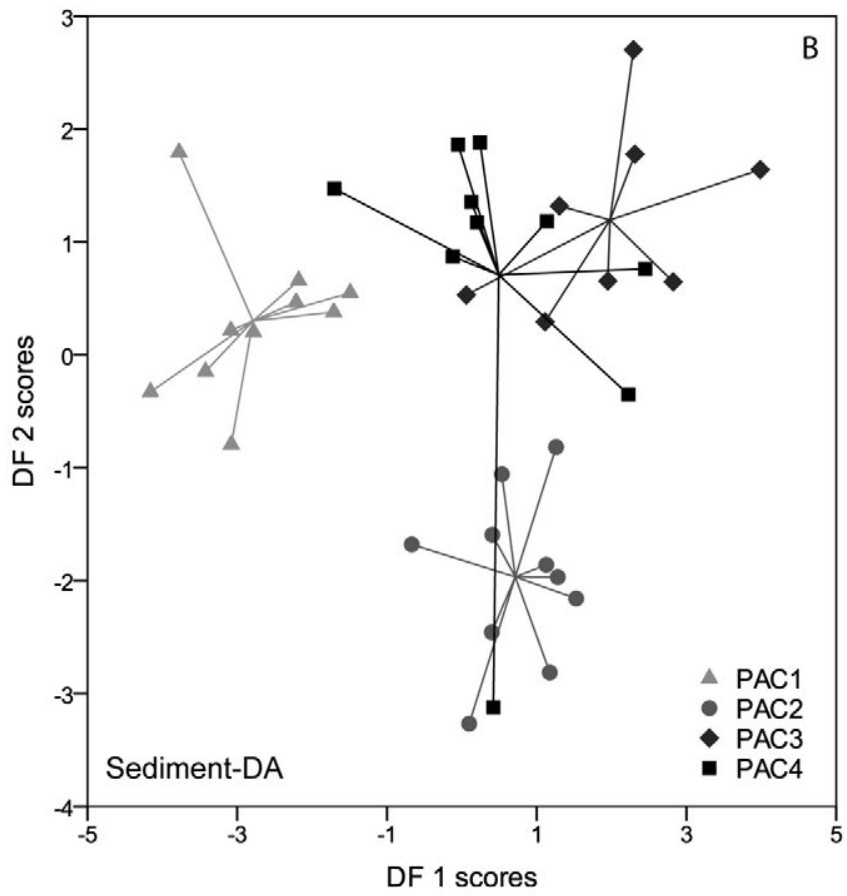

Fig. 3. Scatter plot of the first two functions (DF1 and DF2) of the Discriminant Analysis using water (A) and sediment (B) characteristics to differentiate pond age categories (PAC). 
ponds have been suggested to be driven by a few taxonomic groups, and during succession, new taxa arrive, while some pioneering taxa disappear (Layton, 1991; Ruhí et al., 2009). In addition, an increase in the arrival of passive dispersers or active dispersers having lower dispersal abilities over time has been described (Ruhí et al., 2013). Thus, a balance between the arrival and disappearance of taxa may explain the lack of richness differences among pond age categories. Moreover, the increase in AvTD and VarTD suggests that the new taxa arriving in the manmade ponds belong to distant taxonomic groups (because we detected an increase of the phylogenetic distance among taxa, AvTD) and were unequally distributed in the taxonomic tree (because of the increase of VarTD). The significant increase in rare taxa (IFO values) could be due to the erratic arrival of new taxa and it is reasonable to think this also may contribute to the increase in VarTD values.

Despite the positive tendency detected in AvTD, VarTD and IFO over time, we noticed that PAC alone did not significantly explain the biodiversity of manmade ponds. This means that changes that occur over time were not the main source of biodiversity variability in the macroinvertebrate community of the manmade ponds. Indeed, we found a higher importance of environmental characteristics over pond age explaining the biodiversity variability. Moreover, when differences in water and sediment among PAC were found (the environmental characteristics of PAC1 were different from PAC 2 to 4), we did not detect clear differences in biodiversity metrics (Figs. 2 and 3). The lack of synchronization in the changes in pond characteristics and biodiversity, combined with the significant contribution of the landscape features to the explanation of biodiversity variability (i.e., taxonomic distinctness), suggested that local environmental characteristics may play an important role in the macroinvertebrate community configuration. The biodiversity of the manmade ponds constructed in reclaimed opencast coal mines was low compared to other constructed or restored ponds of similar pond ages (Tab. 4). Indeed, the biodiversity in our study showed lower values than other manmade ponds located in post-mining landscapes, as was the case in Moura (Australia). The low biodiversity values combined with the greater environmental than PAC explanation of the biodiversity variability among ponds suggested that the macroinvertebrate community inhabiting the ponds constructed in the reclaimed coal mines of Teruel were constrained by the particular characteristics of the study area. The homogeneity of the pond habitat (e.g., littoral ponds were dominated by Typha sp. and ponds had similar sediment texture) may be one important reason for the low biodiversity values because faunal biodiversity is positively correlated with the complexity of the pond habitat (O'Connor, 1991; Pedruski and Arnott, 2011). Moreover, it is possible that the manmade ponds were polluted due to coal mining despite mine reclamation. In fact, several metals showed a relevant contribution to the biodiversity explanation (Tab. 3). These metals may contribute to the low biodiversity values due their negative effects over macroinvertebrate community (Clements, 1994; Van Damme et al., 2008; Iwasaki et al., 2009). Finally, the development of the macroinvertebrate community may have been limited by the recruitment of organisms (Palmer et al., 1996; Brady et al., 2002; Brederveld et al., 2011). No natural wetlands or ponds were

Tab. 3. Variables selected from the three groups of explanatory variables (water, sediment and landscape) for each biodiversity metric introduced in the variation partitioning analyses.

\begin{tabular}{|c|c|c|c|c|}
\hline & $\mathrm{RR}$ & AVTD & VARTD & IFO \\
\hline Water & $\begin{array}{c}\text { Chlorophyll-a } \\
\text { Suspended organic matter } \\
\text { Total suspended solids }\end{array}$ & $\begin{array}{c}\mathrm{pH} \\
\text { Non purgueable organic carbon } \\
\text { Total dissolved nitrogen } \\
\mathrm{Al} \\
\mathrm{Fe} \\
\mathrm{Zn}\end{array}$ & $\begin{array}{l}\text { Chlorophyll-a } \\
\text { Non purgueable organic carbon } \\
\text { Total dissolved nitrogen } \\
\mathrm{Ni} \\
\mathrm{Fe} \\
\mathrm{Zn}\end{array}$ & $\begin{array}{c}\text { Chlorophyll-a } \\
\text { Dissolved Oxygen }\end{array}$ \\
\hline Sediment & & $\begin{array}{l}\text { Total carbon } \\
\text { Clay fraction }\end{array}$ & $\begin{array}{c}\text { Total carbon } \\
\text { Clay fraction } \\
\text { Conductivity } \\
\text { As }\end{array}$ & $\begin{array}{c}\text { Total carbon } \\
\text { Total sulphur } \\
\text { Total organic carbon } \\
\text { Total nitrogen } \\
\text { As } \\
\mathrm{Cr} \\
\mathrm{Ni}\end{array}$ \\
\hline Landscape & Littoral vegetation area & $\begin{array}{c}\text { Littoral vegetation area } \\
\text { Pond area }\end{array}$ & $\begin{array}{l}\text { Littoral vegetation area } \\
\text { Pond area } \\
\text { Numbers of ponds in a } 1000-\mathrm{m} \text { buffer }\end{array}$ & \\
\hline
\end{tabular}

$R R$, rarefied richness; AvTD, average taxonomic distinctness; VarTD, variation in taxonomic distinctness; IFO, index of faunal origin. 


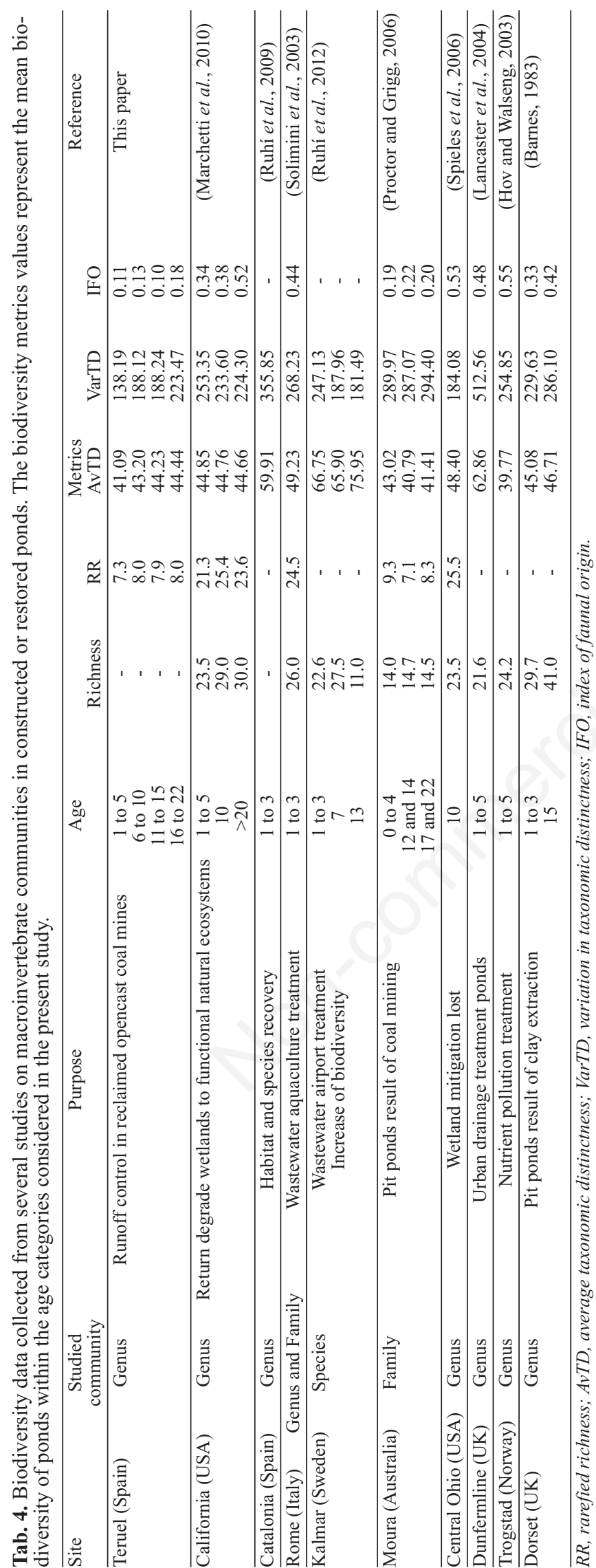

found near the coal mines, and the manmade ponds were isolated from water courses. Therefore, the source of macroinvertebrates may be primarily restricted to distant streams. This fact may reduce the probability of colonizing the manmade ponds because the macroinvertebrate community of lotic ecosystems is different and shows lower dispersal abilities than the macroinvertebrates inhabiting lentic ecosystems (Ribera and Vogler, 2000; Marten et al., 2006).

Comparing biodiversity values with other studies allow to search for temporal biodiversity patterns among different regions. To perform this comparison, we selected AvTD and VarTD because of their lack of dependence on sampling effort allow for a comparison across studies from different localities or from regions using different sampling methods (Clarke and Warwick, 1998). The AvTD vs. VarTD scatter plot (Fig. 4) showed no relationship between biodiversity and pond age when the manmade wetlands and ponds of different study sites were compared. Moreover, neither the geographic area nor the construction objective were determining factors (Tab. 4) similar results were obtained by Ruggiero et al. (2008). Therefore, the local conditions of each study appear to be more important for explaining macroinvertebrate biodiversity than the general patterns.

\section{CONCLUSIONS}

In summary, this study demonstrated that even constructed ponds located in post mining landscapes and without an enhanced biodiversity purpose showed an increase in almost all of the studied biodiversity metrics over time. The only biodiversity metric that did not in-

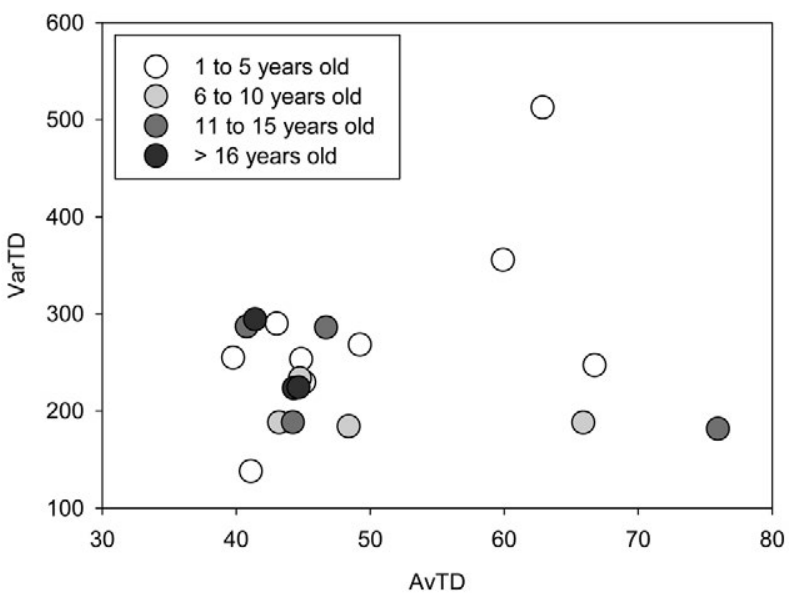

Fig. 4. Scatter plot of variation in taxonomic distinctness (VarTD) against average taxonomic distinctness (AvTD) to compare the biodiversity of 10 different study sites in relation to pond age. Data corresponding to table 4 were used. 
crease is the metric that is mainly used to assess biodiversity (i.e., richness). This fact highlights the importance of using a range of biodiversity metrics to study the macroinvertebrate community, which agrees with previous studies (Wilsey et al., 2005; Heino et al., 2007; Gascón et al., 2009; Gallardo et al., 2011). Our results suggest that environmental factors better explain the configuration of pond biodiversity than pond age. This fact, coupled with the low biodiversity detected in our study area, suggest that environmental conditions may restrict the number and type of taxa that are able to colonize and become established in manmade ponds and therefore restrict the process of the macroinvertebrate community maturation. However, because biodiversity metrics increased over time (except for rarefied richness) and natural ponds are absent from the studied area, manmade ponds constructed during reclamation activities to control runoff may provide both biological and landscape diversity, at least at a regional scale. The study of manmade ponds is a useful tool to understand the functioning of the increasing number of manmade ponds around the world and also provide new ecological information to guide future pond construction.

\section{ACKNOWLEDGMENTS}

This work was supported by a research and assistance agreement between Endesa S.A and the Pyrenean Institute of Ecology-CSIC. The first author was the recipient of a $\mathrm{Ph} . \mathrm{D}$. grant from the Aragón Government (Spain). We are grateful to the people working at the Endesa mines of Teruel and to our fieldwork assistants. We also would like to thank Albert Ruhí for providing the data to calculate some of the biodiversity metrics. Finally we would like to thank to Dr. Céréghino and the other two anonymous reviewer for their helpful comments.

\section{REFERENCES}

APHA, AWWA, WPCF, 1992. [Métodos normalizados para el análisis de aguas potables y residuales].[Book in Spanish]. Díaz de Santos: 1816 pp.

Barnes L, 1983. The colonization of ball-clay ponds by macroinvertebrates and macrophytes. Freshwater Biol. 13:561-578.

Batzer DP, Cooper R, Wissinger SA, 2006. Wetland animal ecology, p. 242-284. In: DP Batzer and RR Sharitz (eds). Ecology of freshwater and estuarine wetlands. University of California Press.

Bilton DT, Mcabendroth L, Bedford A, Ramsay PM, 2006. How wide to cast the net? Cross-taxon congruence of species richness, community similarity and indicator taxa in ponds. Freshwater Biol. 51:578-590.

Bloechl A, Koenemann S, Philippi B, Melber A, 2010. Abundance, diversity and succession of aquatic Coleoptera and Heteroptera in a cluster of artificial ponds in the North German Lowlands. Limnologica 40:215-225.

Boix D, Biggs J, Céréghino R, Hull AP, Kalettka T, Oertli B,
2012. Pond research and management in Europe: 'small is beautiful'. Hydrobiologia 689:1-9.

Boix D, Sala J, Quintana XD, Moreno-Amich R, 2004. Succession of the animal community in a Mediterranean temporary pond. J. N. Am. Benthol. Soc. 23:29-49.

Borcard D, Legendre P, Drapeau P, 1992. Partialling out the spatial component of ecological variation. Ecology 73:1045-1055.

Brady VJ, Cardinale BJ, Gathman JP, Burton TM, 2002. Does facilitation of faunal recruitment benefit ecosystem restoration? An experimental study of invertebrate assemblages in wetland mesocosms. Restor. Ecol. 10:617-626.

Brederveld RJ, Jähnig SC, Lorenz AW, Brunzel S, Soons MB, 2011. Dispersal as a limiting factor in the colonization of restored mountain streams by plants and macroinvertebrates. J. Appl. Ecol. 48:1241-1250.

Céréghino R, Ruggiero A, Marty P, Angélibert S, 2008. Biodiversity and distribution patterns of freshwater invertebrates in farm ponds of a south-western French agricultural landscape. Hydrobiologia 597:43-51.

Clarke K, Warwick R, 1998. A taxonomic distinctness index and its statistical properties. J. Appl. Ecol. 35:523-531.

Clarke K, Warwick R, 2001. A further biodiversity index applicable to species lists: variation in taxonomic distinctness. Mar. Ecol.-Progr. Ser. 216:265-278.

Clements WH, 1994. Benthic Invertebrate community responses to heavy metals in the upper Arkansas River basin, Colorado. J. N. Am. Benthol. Soc.13:30-44.

Corstanje R, Portier KM, Reddy KR, 2009. Discriminant analysis of biogeochemical indicators of nutrient enrichment in a Florida wetland. Eur. J. Soil Sci. 60:974-981.

De Meester L, Declerck S, Stoks R, Louette G, Van De Meutter F, De Bie T, Michels E, Brendonck L, 2005. Ponds and pools as model systems in conservation biology, ecology and evolutionary biology. Aquat. Conserv. 15:715-725.

EPA, 2007. Method3051a: Microwave-assisted acid dissolution of sediments, sludges, soils, and oils. Environmental Protection Agency, Washington.

Fairchild GW, Faulds AM, Matta JF, 2000. Beetle assemblages in ponds: effects of habitat and site age. Freshwater Biol. 44:523-534.

Fairchild GW, Faulds AM, Saunders LL, 1999. Constructed marshes in southeast Pennsylvania: invertebrate foodweb structure, p. 423-446. In: DP Batzer, RB Rader and SA Wissinger (eds.) Invertebrates in freshwater wetlands of North America: ecology and management. J. Wiley \& Sons.

Flory EA, Milner AM, 2000. Macroinvertebrate community succession in Wolf Point Creek, Glacier Bay National Park, Alaska. Freshwater Biol. 44:465-480.

Fukami T, Wardle DA, 2005. Long-term ecological dynamics: reciprocal insights from natural and anthropogenic gradients. P. R. Soc. B 272:2105-2115.

Gallardo B, Gascón S, Quintana X, Comín FA, 2011. How to choose a biodiversity indicator - Redundancy and complementarity of biodiversity metrics in a freshwater ecosystem. Ecol. Indic. 11:1177-1184.

Gascón S, Boix D, Sala J, 2009. Are different biodiversity metrics related to the same factors? A case study from Mediterranean wetlands. Biol. Conserv. 142:2602-2612.

Gee JHR, Smith BD, 1995. The conservation value of farm ponds: macroinvertebrates. Report n. 127 to the Countryside Council for Wales. 
Gee JHR, Smith BD, Lee KM, Griffiths SW, 1997. The ecological basis of freshwater pond management for biodiversity. Aquat. Conserv. 7:91-104.

Gotelli NJ, Colwell RK, 2001. Quantifying biodiversity: procedures and pitfalls in the measurement and comparison of species richness. Ecol. Lett. 4:379-391.

Gutiérrez LT, Fey WR, 1980. Ecosystem succession: a general hypothesis and a test model of a grassland. MIT Press: $247 \mathrm{pp}$.

Hair JF, Black B, Babin B, Anderson RE, Tatham RL, 2005. Multivariate data analysis. Prentice Hall: 816 pp.

Hansson L, Brönmark C, Anders Nilsson P, Åbjörnsson K, 2005. Conflicting demands on wetland ecosystem services: nutrient retention, biodiversity or both? Freshwater Biol. 50:705-714.

Heikkinen RK, Luoto M, Kuussaari M, Pöyry J. 2005. New insights into butterfly - environment relationships using partitioning methods. P. R. Soc. B 272:2203-2210.

Heino J, Mykra H, Hamalainen H, Aroviita J, Muotka T, 2007. Responses of taxonomic distinctness and species diversity indices to anthropogenic impacts and natural environmental gradients in stream macroinvertebrates. Freshwater Biol. 52:1846-1861.

Hooper DU, Chapin FS, Ewel JJ, Hector A, Inchausti P, Lavorel S, Lawton JH, Lodge DM, Loreau M, Naeem S, Schmid B, Setälä H, Symstad AJ, Vandermeer J, Wardle DA, 2005. Effects of biodiversity on ecosystem functioning: a consensus of current knowledge. Ecol. Monogr. 75:3-35.

Hov A, Walseng B, 2003. [Suksesjon av ferskvannsinvertebrater $i$ et nyetablert damsystem i Trogstad kommune].[ Book in Norwegian]. Norsk Institutt for Naturforskning: $50 \mathrm{pp}$.

Hurlbert SH, 1984. Pseudoreplication and the design of ecological field experiments. Ecol. Monogr. 54:187-211.

Iwasaki Y, Kagaya T, Miyamoto K, Matsuda H, 2009. Effects of heavy metals on riverine benthic macroinvertebrate assemblages with reference to potential food availability for drift feeding fishes. Environ. Toxicol. Chem. 28:354-363.

Lake PS, Bayly IAE, Monton DW, 1989. The phenology of a temporary pond in western Victoria, Australia, with special reference to invertebrate succession. Arch. Hydrobiol. 115:171-202.

Lancaster J, Edwards F, Hall K, Hogan A, Towers N, Townsend S, 2004. Duloch Park remediation ponds biomonitoring 1999-2003. Institute of Cell, Animal and Population Biology, University of Edinburgh.

Layton R, 1991. Colonization of new experimental ponds by benthic macroinvertebrates. Environ. Entomol. 20:110-117.

Legendre P, Dallot S, Legendre L, 1985. Succession of species within a community: chronological clustering, with applications to marine and freshwater zooplankton. Am. Nat. 125:257-288.

Loreau M, Naeem S, Inchausti P, Bengtsson J, Grime JP, Hector A, Hooper DU, Huston MA, Raffaelli D, Schmid B, Tilman D, Wardle DA, 2001. Biodiversity and Ecosystem functioning: current knowledge and future challenges. Science 294:804-808.

MacArthur RH, Wilson EO. 1967. Theory of Island Biogeography. Princeton University Press.

MacNally RM, 2002. Multiple regression and inference in ecology and conservation biology: further comments on identifying important predictor variables. Biodivers. Conserv. 11:1397-1401.
MacNally RM, Walsh C, 2004. Hierarchical partitioning publicdomain software. Biodivers. Conserv. 13:659-660.

Majer JD, Nichols OG, 1998. Long-term recolonization patterns of ants in Western Australian rehabilitated bauxite mines with reference to their use as indicators of restoration success. J. Appl. Ecol. 35:161-182.

Marchetti MP, Garr M, Smith ANH, 2010. Evaluating wetland restoration success using aquatic macroinvertebrate assemblages in the Sacramento Valley, California. Restor. Ecol. 18:457-466.

Margalef R, 1968. Perspectives in ecological theory. University of Chicago Press: $111 \mathrm{pp}$.

Marten A, Brändle M, Brandl R, 2006. Habitat type predicts genetic population differentiation in freshwater invertebrates. Mol. Ecol. 15:2643-2651.

Matthews JW, Spyreas G, Endress A, 2009. Trajectories of vegetation-based indicators used to assess wetland restoration progress. Ecol. Appl. 19:2093-2107.

Moreno-Mateos D, Power ME, Comín FA, Yockteng R, 2012. Structural and Functional loss in restored wetland ecosystems. PLoS Biol 10:e1001247.

Myers RH, 1986. Classical and modern regression with applications. Duxbury Press: 359 pp.

Noon KF, 1996. A model of created wetland primary succession. Landscape Urban Plan. 34:97-123.

O'Connor NA, 1991. The effects of habitat complexity on the macroinvertebrates colonising wood substrates in a lowland stream. Oecologia 85:504-512.

Odum EP, 1969. The strategy of ecosystem development. Science 164:262-270.

Oertli B, Joye DA, Castella E, Juge R, Cambin D, Lachavanne JB, 2002. Does size matter? The relationship between pond area and biodiversity. Biol. Conserv. 104:59-70.

Oksanen J, Kindt R, Legendre P, O'Hara B, Simpson GL, Solymon P, Stevens MHH, Wagna H, 2009. Vegan: Community ecological package. $\mathrm{R}$ foundation for statistical computing. R Package Version 1.15-3.

Palmer MA, Allan JD, Butman CA, 1996. Dispersal as a regional process affecting the local dynamics of marine and stream benthic invertebrates. Trends Ecol. Evol. 11:322-326.

Pedruski M, Arnott S, 2011. The effects of habitat connectivity and regional heterogeneity on artificial pond metacommunities. Oecologia 166:221-228.

Peres-Neto P, Legendre P, Dray S, Borcard D, 2006. Variation partitioning of species data matrices: Estimation and comparison of fractions. Ecology 87:2614-2625.

Pinheiro J, Bates D, DebRoy S, Sarkar D, R Core Team, 2012. nlme: linear and nonlinear mixed effects models. R package version 3.1-111.

Proctor H, Grigg A, 2006. Aquatic invertebrates in final void water bodies at an open-cut coal mine in central Queensland. Austr. J. Entomol. 45:107-121.

Puchalski W, 1987. Phytoplankton assemblages in after-exploitation reservoirs. Ph.D. Thesis, Institute of Ecology PAS.

R Core Team, 2012. R: A language and environment for statistical computing. R foundation for Statistical Computing. Vienna, Austria.

Ribera I, Vogler AP, 2000. Habitat type as a determinant of species range sizes: the example of lotic - lentic differences in aquatic Coleoptera. Biol. J. Linn. Soc. 71:33-52. 
Rosenzweig M, 1992. Species diversity gradients: we know more and less than we thought. J. Mammal. 73:715-730.

Ruggiero A, Céréghino R, Figuerola J, Marty P, Angélibert S, 2008. Farm ponds make a contribution to the biodiversity of aquatic insects in a French agricultural landscape. C. R. Biol. 331:298-308.

Ruhí A, Boix D, Gascón S, Sala J, Quintana XD, 2013. Nestedness and successional trajectories of macroinvertebrate assemblages in man-made wetlands. Oecologia 171:545-556.

Ruhí A, Boix D, Sala J, Gascón S, Quintana XD, 2009. Spatial and temporal patterns of pioneer macrofauna in recently created ponds: taxonomic and functional approaches. Hydrobiologia 634:137-151.

Ruhí A, Herrmann J, Gascón S, Sala J, Geijer J, Boix D, 2012. Change in biological traits and community structure of macroinvertebrates through primary succession in a man-made Swedish wetland. Freshwater Sci. 31:22-37.

Sastre J, Sahuquillo A, Vidal M, Rauret G, 2002. Determination of $\mathrm{Cd}, \mathrm{Cu}, \mathrm{Pb}$ and $\mathrm{Zn}$ in environmental samples: microwaveassisted total digestion versus aqua regia and nitric acid extraction. Anal. Chim. Acta 462:59-72.

Solimini AG, Ruggiero A, Bernardini V, Carchini G, 2003. Temporal pattern of macroinvertebrate diversity and production in a new man made shallow lake. Hydrobiologia 506509:373-379.

Spieles D, Coneybeer M, Horn J, 2006. Community structure and quality after 10 years in two Central Ohio mitigation bank wetlands. Environ. Manage. 38:837-852.

Syvitski JPM, 2007. Principles, methods and application of particle size analysis. Cambridge University Press: 388 pp.

Van Damme PA, Hamel C, Ayala A, Bervoets L, 2008. Macroinvertebrate community response to acid mine drainage in rivers of the High Andes (Bolivia). Environ. Poll. 156:1061-1068.

Velasco J, Millán A, Ramírez Díaz L, 1993. [Colonización y sucesión de nuevos medios acuáticos. I. Composición y estructura de las comunidades de insectos].[Article in Spanish]. Limnetica 9:73-86.

Walker LR, Wardle DA, Bardgett RD, Clarkson BD, 2010. The use of chronosequences in studies of ecological succession and soil development. J. Ecol. 98:725-736.

Wang H, Ouyang Z, Chen W, Wang X, Zheng H, Ren Y, 2011. Water, heat, and airborne pollutants effects on transpiration of urban trees. Environ. Poll. 159:2127-2137.

Warwick R, Clarke K, 1995. New 'biodiversity' measures reveal a decrease in taxonomic distinctness with increasing stress. Mar. Ecol.-Progr. Ser. 129:301-305.

Whittaker RJ, Fernández-Palacios JM, 2007. Island biogeography: ecology, evolution, and conservation. Oxford University Press: 416 pp.

Williams PJ, Whitfield M, Biggs J, Bray S, Fox G, Nicolet P, Sear D, 2004. Comparative biodiversity of rivers, streams, ditches and ponds in an agricultural landscape in Southern England. Biol. Conserv. 115:329-341.

Wilsey BJ, Chalcraft DR, Bowles CM, Willig MR, 2005. Relationships among indices suggest that richness is an incomplete surrogate for grassland biodiversity. Ecology 86:1178-1184.

Zedler JB, Callaway JC, 1999. Tracking wetland restoration: do mitigation sites follow desired trajectories? Restor. Ecol. 7:69-73.

Zedler JB, Kercher S, 2005. Wetland resources: status, trends, ecosystem services, and restorability. Ann. Rev. Environ. Resour. 30:39-74. 